\title{
The Government Size - Economic Growth Relationship: Nigerian Econometric Evidence Using a Vector Autoregression Model
}

\author{
Dickson E. Oriakhi ${ }^{1} \&$ Liberty N. Arodoye ${ }^{1}$ \\ ${ }^{1}$ Department of Economics and Statistics, University of Benin, Benin City, Nigeria \\ Correspondence: Liberty N. Arodoye, Department of Economics and Statistics, University of Benin, Benin City, \\ Nigeria. Tel: 234-803-835-0071. E-mail: doye2020@yahoo.com or nosakhare.arodoye@uniben.edu
}

$\begin{array}{lc}\text { Received: January 19, } 2013 & \text { Accepted: March 25, } 2013 \quad \text { Online Published: April 27, } 2013 \\ \text { doi:10.5539/ijbm.v8n10p126 } & \text { URL: http://dx.doi.org/10.5539/ijbm.v8n10p126 }\end{array}$

\begin{abstract}
This study examines the relationship between government size and economic growth in Nigeria using annually time series data for 1970 through 2010.In order to fully account for feedbacks, a vector autoregression model is utilized. The results show that there is a long-run relationship between government size and economic growth. The Forecast Error Variance Decomposition results show that the main sources of Nigeria economic growth variation are due largely to "own shocks", government size and real gross domestic product per head innovations. This study therefore recommends adoption of government activities expansion as a means of accelerating economic growth in Nigeria.
\end{abstract}

Keywords: government size, economic growth, VAR, Nigeria

\section{Introduction}

Public spending is widely seen as having an important role in supporting long- run economic growth, the size of government expenditures. Expenditure on the Gross Domestic Product at current market prices stood at N29,498.16 billion and N25,860.63 billion at the end of 2010 and 2009 respectively, reflecting a marginal rise from N25, 424.95 billion in 2008.Disaggregation of these figures show that government final consumption expenditure stood at N2,926.0 billion, N2,803.98 billion and N4,265.93 billion in 2008, 2009 and 2010 respectively. Private final consumption expenditure registered N17,072.18 billion, N20,285.5 billion and N17,539 billion in 2008, 2009 and 2010 respectively. Total final consumption expenditure accounted for $78.66 \%$ and $89.28 \%$ in 2008 and 2009 respectively while gross fixed capital formation accounted for $7.99 \%$ and $11.57 \%$ respectively (National Planning Commission, 2011).

This study examines the relationship between government size and economic growth in Nigeria for the period of 1970 to 2010 using a Vector Auto regression (VAR) model. Section 2.0 reviews the theoretical and empirical literature relating to economic growth and government size, while section 3.0 presents the methodology and model specification. Section 4.0 discusses the econometric results while 5.0 conclude the paper.

\section{Government Size and Economic Growth: Theory and Empirics}

The rise of public expenditure has been a subject of extensive theoretical and empirical examinations over decades. One of the theoretical explanations that have been examined is Wagner's law which has been used to analyze the relationship between aggregate income and public expenditure. Wagner (1890), on the basis of his empirical findings noted that there was a long run tendency for state activities to grow relative to the growth in national income. He further stated that as the real income per capita of a nation increases, the share of public expenditures in total economic activities increases, and empirically show a simple positive correlation between a nation's Gross Domestic Product(GDP) and Government size(G).Following Archarya (2012), Wagner proposed a functional relationship that shows government expenditure(GE) as a partial function of the Gross Domestic Product (GDP).According to him, this basic hypothesis has been proposed in six different basic models:

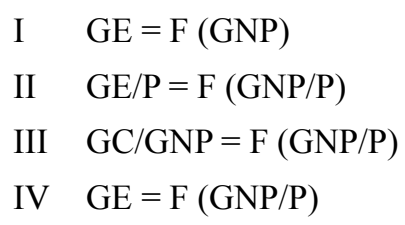




\section{$\mathrm{V} \quad \mathrm{GE} / \mathrm{GNP}=\mathrm{F}(\mathrm{GNP} / \mathrm{P})$ and}

\section{VI $\quad \mathrm{GE} / \mathrm{GDP}=\mathrm{F}(\mathrm{GDP})$}

Where, GE, P, GC and GNP represent government expenditure, price index, government consumption and gross national product and the symbol $\mathrm{F}$ in all equations signifies a functional relationship between the dependent and explanatory variables.

In addition to the work of Wagner, Peacock and Wiseman (1961), made a generalization about the relation between government expenditure and GNP with concerns for social and economic change that require examination, and not with "inevitable" results of such change. Also, in a separate study by Iyoha (2007) he further noted that in More Developed Countries (MDCs), growth in public expenditure has been propelled by the steady increase in transfer payments and other subsidies. In the Less Developed Countries (LDCs), growth in government expenditure has been further driven by increased spending on social and community services, and on the servicing of external debt.

Endogenous growth theories in the past decades has generated interest in models of growth with fiscal policy, following the work of Barro (1990) he begins with endogenous growth models that build on constant returns to a broad concept of capital, and later developed a model where government plays an active role in influencing long run growth. It is this productive role that creates a potentially positive linkage between government and growth. On the other hand, the potential growth gains from what Barro calls productive government spending is higher in endogenous models. Formally, endogenous growth models use production functions like $\mathrm{Y}=\mathrm{AK}$, where $\mathrm{A}$ is a parameter capturing the level of technology, $\mathrm{Y}$ is output per capita, and $\mathrm{K}$ is capital per capita. Capital in this model is of a broad sense that includes human capital (Barro and Martin, 2004). In the work of Herath (2010), he noted that based on the Solow's neoclassical theory, economic growth is an effect of an external cause and further explained that instituted policies by the government cannot directly affect growth except in the period of transition to a steady state.

Udah (2012) in his study pointed out that government size variable is not a significant factor in influencing private investment decisions in Nigeria despite the huge government expenditure over the last two decades in capital projects related to infrastructure.

According to Afonso and Furceri (2008), some increase in the size of the public sector is to be expected when taking into account past rising population and also to meet the broading requirements of the welfare state in most countries. They further noted that a larger public sector, as measured by the share of government expenditures in GDP, does not necessarily imply a better satisfaction of public requirements or, for that matter, a more efficient approach to providing the minimum required benefits of the welfare state.

\subsection{Government Size and Economic Growth: The Empirical Evidence}

The study by Ramafyandi (2003) examined how the size of government in Indonesia impact on the country's economic growth from 1969 to 1999 , his finding shows that government size tend to have negative effects on economic growth. The study further noted in conducting the Error Correction Model test that such negative relationship will continue both in the short and long run respectively. Contrary to this study, in a separate study by Bergh and Henrekson (2011) in examining the relationship between the size of government and economic growth conducting a cross country regression using panel data, their results do not imply that government must shrink for growth to increase. They noted that there is potential for increasing growth by restructuring taxes and expenditure so that the negative effects on growth for a given government size are minimized.

However, in the study by Ogbonna (2012) in examining the validity of Wagner's law in Nigeria, using annual time series data and adopting the Johansen Maximum likelihood Co integration method, Error Correction Modeling and Granger Causality test for unidirectional causality stemming from Real GDP per capita to Government size. The results further reveal that the tendencies for long run economic activities to grow relative to growth in national income are possible in Nigeria.

The study of Safdari et al (2011) in examining the relationship between Government size and economic growth in Iran using the Vector Auto regression (VAR) model considered the balance relation and long term of six variables, growth rate of Gross Domestic Product, the ratio of private investment to GDP, population growth rate, the ratio of government expenditure to GDP, young age dependency ratio and old age dependency ratio have a negative effect on Gross Domestic Product growth rate.

Fan and Rao (2003) in their study investigated the trends in government expenditures in the developing world in order to access the causes of change and to develop an analytical framework for determining the differential impacts of various government expenditures on economic growth. Contrary to common belief, their study found 
that structural adjustment programs increased the size of government spending but not all sectors received equal treatment.

\section{Empirical Methodology}

Like many studies which have recently investigated the nexus between Government size and economic growth, this study utilizes the techniques of Vector Auto regressions (VARs). Use of the VAR technique has become attractive since the Nobel Laureate, Sims (1986), demonstrated that Vector Autoregression models are particularly powerful tools for investigating the inter-relationships among time-series variables and for obtaining reliable forecasts. VARs have indeed made it possible for researchers to address both the relative importance and the dynamic effects of various shocks on macroeconomic variables. Additionally, the study carries out Unit roots tests, co integration and pair-wise Granger Causality Tests of the variables. Forecast Error Variance Decomposition (FEVD) and Impulse Response Functions (IRFs) are applied to examine interrelationships between the variables in the VAR system. This study posits a 3- variable VAR model in which growth rate of Real Gross Domestic Product, Government size and Real Gross Domestic Product per head are simultaneously interrelated. Thus, the VAR model specified is:

$$
V_{t}=\alpha+\sum_{i=1}^{k} A_{i} V_{t-1}+U_{t}
$$

$\mathrm{V}_{\mathrm{t}}=\mathrm{F}$ (RGDPGR, GOVSZ, RGDPPH).

$V_{t}=$ the vector of growth rate of Real Gross Domestic Product, Government size and Real Gross Domestic per head.

$\alpha=$ matrix of coefficients of autonomous variables.

$\mathrm{Ai}=$ the matrix of coefficients of all the variables in the model.

$\mathrm{V}_{\mathrm{t}-1}=$ is the vector of the lagged values of the growth rate of Real Gross Domestic Product, Government Size and Real Gross Domestic Product per head.

$\mu_{\mathrm{t}}=$ the vector of the error terms.

The apriori expectations of the coefficients in the specified models above.

Table 1. Variable descriptions and apriori expectations

\begin{tabular}{llc}
\hline Variables & Variable Description & Expected signs of coefficient \\
\hline RGDP & $\begin{array}{l}\text { Growth rate of Real Gross Domestic Product (Proxy for the } \\
\text { Nigeria's economic growth) } \\
\text { GOVSZ }\end{array}$ & $\begin{array}{l}\text { Government Size (measured by the ratio of total government } \\
\text { expenditure to Real Gross Domestic Product) }\end{array}$ \\
RGDPPH & $\begin{array}{l}\text { Real Gross Domestic Product per Head (Measured by the ratio of } \\
\text { Real Gross Domestic Product to population size), Used as an } \\
\text { indicator of the overall economic Well-being }\end{array}$ \\
\hline
\end{tabular}

Source: Author.

\section{Econometric Results}

Below we present the descriptive statistics, unit root tests, Johansen co-integration test, Pairwise Granger Causality Tests, Forecast Error Variance Decomposition (FEVD) and Impulse Response Functions (IRFs). The time series data on the variables that are utilized in this study were tested for stationarity, using the Augumented Dickey -Fuller (ADF) test. The Co-integration test provides valuable information on the existence of a long run relationship between the variables. The Granger causality test examines the causal relationships between the growth rates of Real Gross Domestic Product, Government size and Real Gross Domestic Product per head in Nigeria. To analyze the dynamic effects of the variables, we employ the Forecast Error Variance Decomposition and Cholesky Impulse Response Analysis. 


\subsection{Summary Descriptive Statistics Results}

Summary descriptive statistics of the growth rate of RGDP, Government size and the RGDP per head are reported in Table 2. Normality test uses the null hypothesis of non-normality. If the probability value is less than the Jacque Bera chi-square at the 5\% level of significance, the null hypothesis of the regression is not rejected. All the variables are normally distributed since all the probabilities are less than the Jacque Bera chi-square distribution. We utilize the mean based coefficient of skewness and kurtosis to check the normality of all the variables. Skewness measures the direction and degree of symmetry. The skewness coefficient indicates normal curve for government size and Real Gross Domestic Product per head with the values ranging between -3 and +3 , except for growth rate of RGDP which exceeded the bound in this study.

Table 2. Summary of descriptive statistics

\begin{tabular}{lccc}
\hline Statistics & RGDPGR & RGDPPH & GOVSZ \\
\hline Mean & 25.16098 & 1918.861 & 0.189451 \\
Median & 6 & 390.0977 & 0.178797 \\
Maximum & 550.5 & 13594.99 & 0.301588 \\
Minimum & -7.3 & 204.2784 & 0.104392 \\
Std. Deviation & 90.12683 & 3635.817 & 0.054628 \\
Skewness & 5.187032 & 2.469195 & 0.566521 \\
Kurtosis & 29.94696 & 7.569351 & 2.3315587 \\
Jarque - Bera & 1424.339 & 77.33056 & 2.956374 \\
Probability & 0 & 0 & 0.228051 \\
Sum & 1031.6 & 78673.3 & 7.767474 \\
Sum Sq. Dev. & 324913.8 & 5.29 & 0.119371 \\
Observation. & 41 & 41 & 41 \\
\hline
\end{tabular}

Source: Author's Computation Using E-Views 7.0.

\subsection{Result of ADF Unit Root Test for Variables}

Unit root test of the variables indicates that all the variables are either I (0) or I (1) series. Given the results reported in Table 3A and 3B, we found out that RGDPGR and GOVSZ were stationary at both levels and first difference. The RGDPPH was only found stationary at first difference. With the results we are justified to conduct co-integration and Granger Causality tests between RGDPGR, GOVSZ and RGDPPH.

Table 3A. ADF unit root test results at levels

\begin{tabular}{lcccc}
\hline Variables & ADF Test Stat. & $\mathbf{9 5 \%}$ critical Value & Order of Integration & Remarks \\
\hline RGDPGR & -6.283776 & -2.936942 & I $(0)$ & Stationary \\
GOVSZ & -3.691896 & -2.936942 & I $(0)$ & Stationary \\
RGDPPH & -1.910430 & -2.954021 & I $(0)$ & Non Stationary \\
\hline
\end{tabular}

Source: Author's Computation Using E-Views 7.0.

Table 3B. ADF unit root test results at first difference

\begin{tabular}{lcccl}
\hline Variables & ADF Test Stat. & $\mathbf{9 5 \%}$ critical Value & Order of Integration & Remarks \\
\hline RGDPGR & -10.18012 & -2.938987 & I $(1)$ & Stationary \\
GOVSZ & -9.256522 & -2.938987 & I (1) & Stationary \\
RGDPPH & -11.27634 & -2.95021 & I $(1)$ & Stationary \\
\hline
\end{tabular}

Source: Author's Computation Using E-Views 7.0. 


\subsection{Johansen Co-Integration Test Results}

The results of the multivariate co-integration test based on Johansen's co-integration techniques reveal that both the Trace Statistics and Maximum Eigen-value Statistics confirm the existence of co-integrating equations among the variables. Since the variables are co-integrated, the existence of a long- run relationship between the growth rate of Real GDP, Government size and Real GDP per head is confirmed. See Table 4 below.

Table 4. Results of Johansen co integration test

\begin{tabular}{|c|c|c|c|c|c|c|}
\hline $\begin{array}{c}\text { No. of co integrating } \\
\text { Equations }\end{array}$ & $\begin{array}{c}\text { Max. Eigen } \\
\text { Value Statistics }\end{array}$ & $\begin{array}{l}0.05 \text { Critical } \\
\text { Value }\end{array}$ & P-Value & Trace Statistics & $\begin{array}{c}\text { 0.05 Critical } \\
\text { Value }\end{array}$ & P-Value \\
\hline None & 23.82397 & 21.13162 & 0.0204 & 46.18273 & 29.79707 & 0.0003 \\
\hline Atmost 1 & 15.42373 & 14.26460 & 0.0326 & 22.35876 & 15.49471 & 0.0039 \\
\hline Atmost 2 & 6.935034 & 6.935034 & 0.0084 & 6.935034 & 3.841466 & 0.0084 \\
\hline
\end{tabular}

Source: Author's Computation Using E-Views 7.0.

\subsection{Results of Pair-Wise Granger Causality Tests}

The empirical results reveal unidirectional causalities between GOVSZ and RGDPGR, GOVSZ and RGDPPH but no causality exist between RGDPPH and RGDPGR. The results show that the growth rate of Real Gross Domestic Product (RGDPGR), Government size (GOVSZ) and Real Gross Domestic Product per head (RGDPPH) are strong causal factors for Government size in Nigeria. See Table 5 below.

Table 5. Summary of pair-wise granger causality test

\begin{tabular}{llll}
\hline Variables & Nature of Causality & Significance Level & Remarks \\
\hline RGDPPH and RGDPGR & No Causality & Undefined & No Feedback \\
GOVSZ and RGDPGR & Unidirectional & 5 percent & Partial Feedback \\
GOVSZ and RGDPPH & Unidirectional & 1 and 5 percent & Partial Feedback \\
\hline
\end{tabular}

Source: Author's Computation Using E-Views 7.0.

\subsection{Results of Forecast Error Variance Decomposition}

To further examine the dynamic effects of growth rate of RGDP, Government size and RGDP per head in Nigeria, we examined the Forecast Error Variance Decomposition (FEVD). The test results for the three variables were obtained, presented and fully analyzed.

An examination of the variance decomposition of RGDPGR in table 6 shows that a substantial amount of the variation experienced by RGDPGR is attributed to its own shock $(100 \%)$ in the first period, but the shock fades out gradually to about $87.7 \%$ at the end of the horizon. The contribution of GOVSZ marginally follows an increasing trend from the first to the third period, but decreases at an increasing rate till the end of the horizon where it stood at $10.7 \%$. Meanwhile, RGDPPH marginally follows an increasing trend till the end of the horizon.

Table 6. Variance decomposition of growth rate of real gross domestic product

\begin{tabular}{lcccc}
\hline Periods & S.E & RGDPGR & RGDPPH & GOVSZ \\
\hline 1 & 91.14881 & 100 & 0 & 0 \\
2 & 96.82254 & 89.01376 & 0.211894 & 10.77434 \\
3 & 97.84478 & 88.58365 & 0.648314 & 10.76803 \\
4 & 98.23101 & 88.12421 & 1.182681 & 10.69311 \\
5 & 98.37966 & 87.86122 & 1.453451 & 10.68532 \\
6 & 98.43225 & 87.77648 & 1.53421 & 10.68931 \\
7 & 98.46881 & 87.73697 & 1.57943 & 10.6836 \\
8 & 98.49308 & 87.70612 & 1.615266 & 10.67861 \\
9 & 98.50784 & 87.68575 & 1.638636 & 10.67561 \\
10 & 98.51636 & 87.67406 & 1.652079 & 10.67386 \\
\hline
\end{tabular}

Source: Author's Computation Using E-Views 7.0. 
An analysis of the variance decomposition of RGDPPH in table 7 shows that a large amount of the variations experienced by RGDPPH is attributed to its own shock ranging between about 69.2 to 74.2 percent within the time horizons. The contribution of RGDPGR moderately follows a decreasing trend till the end of the period where it stood at about 27 percent. Meanwhile, GOVSZ negligibly follows a decreasing trend till the end of the horizon.

Table 7. Variance decomposition of real gross domestic product per head

\begin{tabular}{lclll}
\hline Periods & S.E & RGDPGR & RGDPPH & GOVSZ \\
\hline $\mathbf{1}$ & 1119.688 & 30.78772 & 69.21228 & 0 \\
2 & 1478.817 & 28.99834 & 70.98601 & 0.015652 \\
3 & 1639.596 & 27.11056 & 72.98601 & 0.022996 \\
4 & 1723.508 & 26.33613 & 73.643 & 0.020869 \\
5 & 1768.955 & 26.06576 & 73.91055 & 0.023693 \\
6 & 1794.841 & 25.92418 & 74.04646 & 0.029357 \\
7 & 1809.46 & 25.8361 & 74.13 & 0.033899 \\
8 & 1817.644 & 25.78557 & 74.17732 & 0.037115 \\
9 & 1822.225 & 25.75784 & 74.20268 & 0.039474 \\
10 & 1824.792 & 25.74235 & 74.2165 & 0.041146 \\
\hline
\end{tabular}

Source: Author's Computation Using E-Views 7.0

An assessment of the variance decomposition of GOVSZ in table 8 shows that a large amount of the variations witnessed by GOVSZ is attributed to its own shock ranging between about 89 to 96 percent within the time horizons, but the shock were noticed to fade out gradually towards the end of the horizon. The contribution of RGDPGR marginally follows an increasing trend till the end of the period where it stood at about 2.5 percent. Meanwhile, RGDPPH moderately follows an increasing trend till the end of the horizon.

Table 8. Variance decomposition of government size

\begin{tabular}{lclll}
\hline Periods & S.E & RGDPGR & RGDPPH & GOVSZ \\
\hline 1 & 0.048204 & 0.171708 & 4.272419 & 95.55587 \\
2 & 0.054077 & 2.188566 & 8.128378 & 89.68306 \\
3 & 0.056385 & 2.060752 & 7.592607 & 90.34664 \\
4 & 0.057173 & 2.126119 & 7.388842 & 90.48504 \\
5 & 0.057611 & 2.199978 & 7.455549 & 90.34447 \\
6 & 0.057872 & 2.273543 & 7.624545 & 90.10191 \\
7 & 0.058036 & 2.347973 & 7.808457 & 89.84357 \\
8 & 0.058143 & 2.409182 & 7.974458 & 89.61636 \\
9 & 0.058215 & 2.45302 & 8.106747 & 89.44023 \\
10 & 0.058262 & 2.482834 & 8.202944 & 89.31422 \\
\hline
\end{tabular}

Source: Author's Computation Using E-Views 7.0.

4.6 Impulse Response Function Analysis

The empirical results show the interactions among variables. It traces out the response of the dependent variable in the VAR system to the shocks in the error term, and the result was consistent with the Forecast Error Variance Decomposition (FEVD) results. Results are summarized in figure 1 below. 
Response to Cholesky One S.D. Innovations
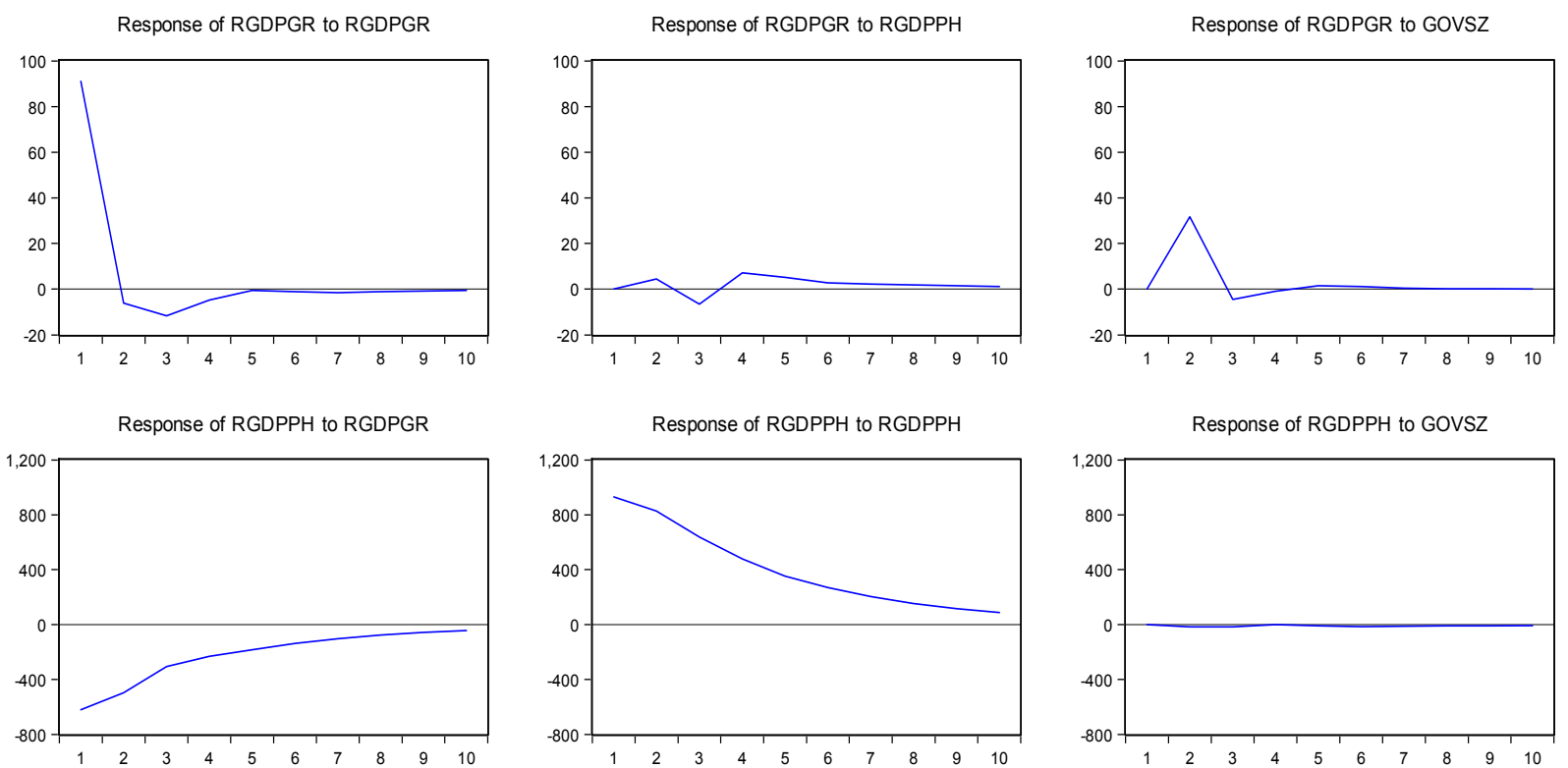

Response of GOVSZ to RGDPGR
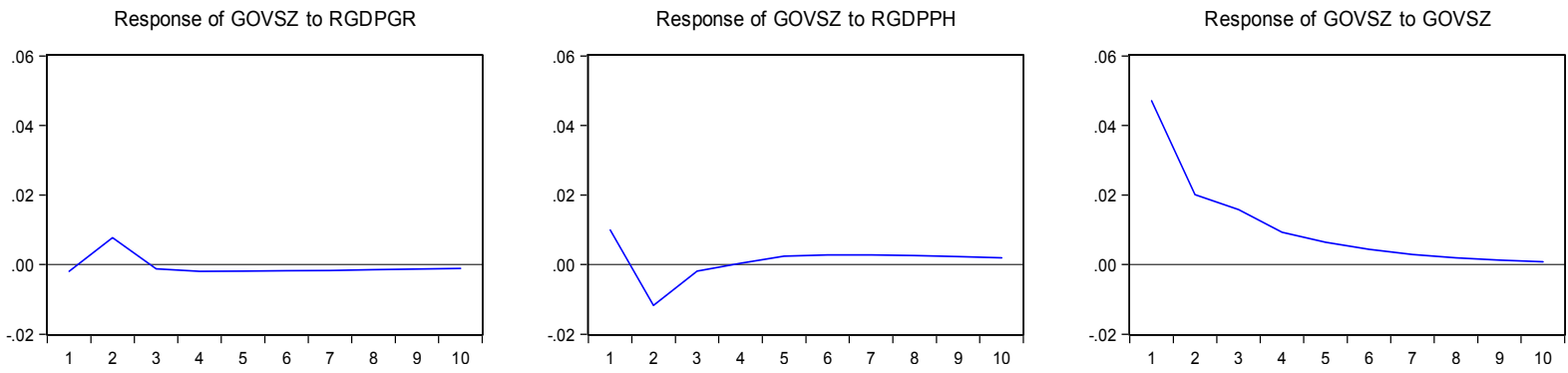

Figure 1. Cholesky impulse response functions (IRFs)

Source: Author's Computation using E-Views 7.0.

\section{Summary, Conclusion and Policy Recommendation}

This paper has analyzed the relationship between economic growth and government size in Nigeria using the Vector Autoregression (VAR) methodology. The results of the unit root tests showed that all the variables are stationary either in their levels (growth rate of RGDP and government size) or first difference (RGDPGR, GOVSZ and RGDPPH).The Johansen Co-integration test showed a long-run relationship between the variables. The Granger causality tests showed that there is a unidirectional causality between Government size and Real GDP, Government size and RGDP per head, but no causality exist between RGDPPH and RGDPGR in Nigeria. The results of the Forecast Error Variance Decompositions (FEVD) test indicated that innovations in the variables are mostly explained by their own shocks. The impulse responses of the growth rate of Real Gross Domestic Product, Government size and Real Gross Domestic Product per head with respect to identified shocks (innovations) are consistent with the results of Variance Decomposition Analysis. Based on the results obtained, the study supports previous researches that find out positive relationship between Government size and economic growth. We recommend that fiscal policies in favour of Government size expansion alongside the appraisal of government spending should be encouraged because the increase in the size of Government activities are key drivers of economic growth in Nigeria.

\section{References}

Afonso, A., \& Furceri, D. (2008). Government Size, Composition, Volatility and Economic Growth. European Central Bank Working Paper Series No. 849, pp. 4-42.

Archarya, S. P. (2012). Growth and Public Expenditure Management: P-value Analysis and Granger Causality in SAARC Economies. SIU Journal of Management, 2(1), 40-58.

Barro, R. J. (1990). Government Spending in a simple model of endogenous growth. Journal of political 
Economy, 98, 103-125. http://dx.doi.org/10.1086/261726

Barro, R. J., \& Sala-i-Martin, X. (2004). Economic growth (2nd ed.). Cambridge and London: MIT Press.

Central Bank of Nigeria Statistical Bulletin. (2010). Vol. 21.

Fan, S., \& Rao, N. (2003). Public Spending in developing countries, trend determination and impact. Environment and production Technology Division EPIY Discussions Paper No. 99.

Guffman, I. J. (1968). Public Sector Growth, An Econometric Test of Wagner's law. Economic and Financial Review, 35(3).

Gupta, S. P. (1967). Public Expenditure and Economic Growth: A Time Series Analysis. Public Finance, 22, 432-461.

Herath, S. (2010). The Size of the government and Economic Growth: An Empirical Study of Sri Lanka. Working Paper.

Iyoha, M. A. (2007). The Government Sector, Intermediate Macroeconomics (pp. 125-155). Benin: Mindex Press Limited.

Mann, A. J. (1980). Wagner's law: An Econometric Test for Mexico. National Tax Journal, 33, 189-201.

Musgrave, R. A. (1969). Fiscal System. New Haven: Yale University Press.

National Bureau of Statistics. (2012). Gross Domestic Product for Nigeria (Expenditure and Income) 2007 Q1 2010Q4. Retrieved on $10^{\text {th }}$ December 2012 from http://www.nigerianstat.gov.ng

National Planning Comission. (2011). Annual Performance of the Nigerian Economy. Retrieved on $10^{\text {th }}$ December, 2012 from http://www.google.com

Ogbonna, B. C. (2012). Does the Wagner's law holds for Nigeria? $1950-2008$. Retrieved on $10^{\text {th }}$ December 2012 from http://www.transcampus.org

Peacock, A. T., \& Wiseman, J. (1961). The Growth of Public Expenditure in the United Kingdom. National Bureau of Economic Research, 1-33.

Peacock, A. T., \& Wiseman, J. (1967). The Growth of Public Expenditure in the United Kingdom. London: George Allen and Unwin.

Ramayandi A. (2003). Government Size in Indonesia: Some lessons for the local Authorities. Working Paper in Economics and Development Studies No 200302, pp. 1-13.

Safdari M. M., Mehrizi, A., \& Elahi. (2011). Government Size and Economic Growth in Iran. International Research Journal of Finance and Economics, 1-7.

Sims, C. A. (1986). Are Forecasting Models Usable for Policy Analysis? Federal Reserve Bank of Minneapolis Quarterly Review, 10(Winter 1986), 2-16.

Udah, E. B. (2012). Macroeconomic Reforms, Government Size, and Investment Behaviour in Nigeria: An Empirical investigation. European Journal of Social Sciences, 33(2), 298-311.

Wagner, A. (1890). Finanzwissenchaft, leipz, winter, CF. 